\title{
Topographic anatomical study of the sciatic nerve relationship to the posterior portal in hip arthroscopy
}

\section{Estudo anatômico topográfico da relação do nervo ciático com o portal posterior nas artroscopias de quadril}

\author{
Berliet Assad Gomes"; Max Rogério Freitas Ramos²; Rossano Kepler Alvim Fiorelli, tCbC-RJ3; Camila Rodrigues de Almeida;
} Stênio Karlos AlVIm FiorelLI²

\section{A}

\begin{abstract}
Objective: To evaluate the anatomic topographic relation between the sciatic nerve in relation to the piriform muscle and the posterior portal for the establishment of hip arthroscopy. Methods: We dissected 40 hips of 20 corpses of adult Brazilians, 17 male and three female, six black, six brown and eight white. We studied the anatomical relationship between the sciatic nerve and the piriform muscle with their variations and the distance between the lateral edge of the sciatic nerve and the posterior portal used in hip arthroscopy. We then classified the anatomical alterations found in the path of the sciatic nerve on the piriform muscle. Results: Seventeen corpses had bilateral relationship between the sciatic nerve and the piriform muscle, i.e., type A. We found the following anatomical variations: $12.5 \%$ of variant type B; and an average distance between the sciatic nerve and the portal for arthroscopy of $2.98 \mathrm{~cm}$. One body had type B anatomical variation on the left hip and type A on the right. Conclusion: the making of the posterior arthroscopic portal to the hip joint must be done with careful marking of the trochanter massive; should there be difficult to find it, a small surgical access is recommended. The access point to the portal should not exceed two centimeters towards the posterior superior aspect of the greater trochanter, and must be made with the limb in internal rotation of 15 degrees.
\end{abstract}

Key words: Arthroscopy. Hip. Anatomic variation. Sciatic nerve. Orthopedics.

\section{INTRODUCTION}

$\mathrm{H}$ ip arthroscopy is a procedure in full development in orthopedic surgery. It had its first citation in 1931, in the report of Michael Samuel Burman 1, but its first clinical application was only carried out in 1939 by Kenji Takagi 2. Since then, little had been published on the subject, when, in 1987, James Michael Glick et al. innovated with the positioning of the patient in the lateral decubitus and the development of arthroscopic material with greater precision $^{3}$.

The hip is often regarded as the most complex joint for arthroscopic surgery for various reasons, such as the need for special equipment, the abundant mantle of soft tissues, the anatomical configuration of the femoral head and the acetabular cavity, leading to the need for mechanical traction to get access to the joint space ${ }^{4}$. Still in improvement curve, this procedure has presented satisfactory results, as well as complications such as nerve damage, which, in most cases, are transitory and are related to the prolonged surgical time, and especially the excessive force used during the use of the orthopedic traction table ${ }^{5}$.

We must consider the significant number of important structures that pass around the hip joint: the femoral neurovascular bundle, anteriorly, the lateral cutaneous nerve of the thigh in the anterolateral aspect and, in the posterior region, gluteal vessels and the sciatic nerve. In view of this anatomical complexity, the correct preparation of all arthroscopic portals to the hip is imperative. The posterior paratrochanteric portal (or, simply, posterior portal) is valuable, but can endanger key structures. This portal is made at a distance of two to three inches further to the apex of the greater trochanter, with the hip in neutral position or slight internal rotation, to prevent the sciatic nerve to be brought close to the portal with the external rotation maneuver. The posterior portal offers the best view of the Weitbrecht ligament, the posterior capsule and the lower-end ischiofemoral ligament. One should made a small open access to create this portal, due to the proximity of the upper gluteal vessels and the sciatic nerve, with delicate dissection of the

1. Service of Experimental Surgery, Gafrée Guinle University Hospital, Rio de Janeiro, Rio de Janeiro State - RJ, Brazil; 2. Department of General and Specialized Surgery, Federal University of the State of Rio de Janeiro; 3. Department of Surgery, Gafrée Guinle University Hospital; 4. Neurology Service, Gafrée Guinle University Hospital. 
external rotators of the hip muscles. The combination of the two techniques (open and arthroscopic) can make the procedure safer and less traumatic ${ }^{5}$. It is worth remembering that other anatomical structures may be at risk in other portals: the lateral cutaneous nerve of the thigh, the ascending branch of the femoral circumflex artery and lateral femoral nerve in the anterior portal, and in the lateral portal, superior gluteal artery and nerve 6-9, as well as the possible variations of the path of the sciatic nerve in relation to the piriform muscle 10-12.

The objective of this study is to evaluate the anatomic topographic relation between the sciatic nerve in relation to the piriform muscle, and the posterior portal for the establishment of hip arthroscopy.

\section{METHODS}

We studied 40 gluteal regions from 20 corpses of Brazilian adult subjects, 17 male and three female, five black, seven brown and eight whites. The dissections were performed at the Departments of Functional Morphology of the Souza Marques Educational Technical Foundation (FTESM) and of the School of Medicine of the Federal University of the State of Rio de Janeiro. The project was approved by the Ethics in Research Committee under registry 05206612.70000 .5258$.

The cadavers were prepared with $10 \%$ formaldehyde (4L) and glycerin (1L) injection. We created the posterior portal for hip arthroscopy, slightly posterior and superior to the apex of the greater trochanter, and placed the trocar suitable for the procedure. After that, we began the process of dissection, with the bodies in prone position on a table suitable for the procedure. We performed the cutaneous approach through three incisions, the first starting at the level of the posterior superior iliac spine and extending medially and transversely to the base of the sacrum; the second, beginning in the inner face of the thigh root, passing along the gluteal fold and ending in its lateral edge; and the third, vertical-orientated, joining the middle part of the first two.

After the completion of the skin access we created two flaps of skin and subcutaneous tissue, which were then folded, one laterally, the other medially. In the next plane we opened the gluteal fascia in the same direction as the superficial access, exposing the gluteus maximus muscle, which, after appropriate view, was sectioned in the transition between its middle and distal third with a cut made perpendicular to the muscle fibers, forming a medial, proximal flap and a distal, lateral one. In the underlying plane, we found the gluteus medius muscle and adipose conjunctival areolar tissue, which we resected, exposing the external rotator muscles of the hip and the sciatic nerve. To facilitate the analysis and documentation of findings in all gluteal regions, the nerve was painted with yellow paint in its exposure path and the piriform muscle in red from its origin in the pelvis to its insertion in the greater trochanter (Figures 1 and 2).

In each of the gluteal regions, we observed the relationship between the sciatic nerve and the piriform muscle, analyzing the possible anatomical variations existing in this region and employing Beaton and Anson classification for each hip (Table 1) ${ }^{11}$. Then, we measured the distance between the nerve lateral margin (fibular component) and the arthroscopic trocar inserted in the posterior portal for the procedure, with the hip in neutral rotation (Figure 3). We performed a descriptive statistical analysis using the mean, median, minimum and maximum values. For analytical statistics of the variables, we used the nonparametric Wilcoxon test and the test for independent variables, considering $p<0.05$ significant.

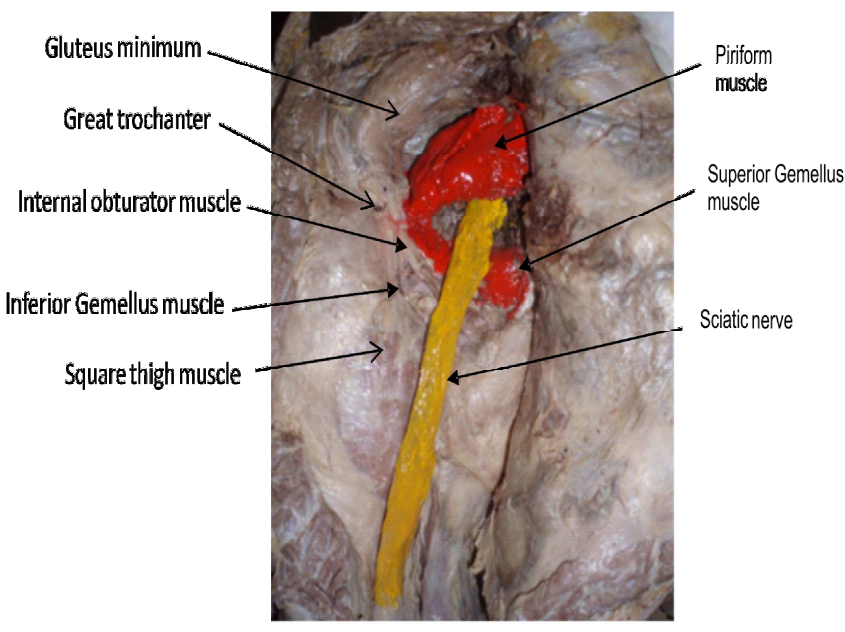

Figure 1 - Dissected gluteal region showing type A path of the sciatic nerve in relation to the piriform muscle, according to the criteria of Beaton ${ }^{11}$.

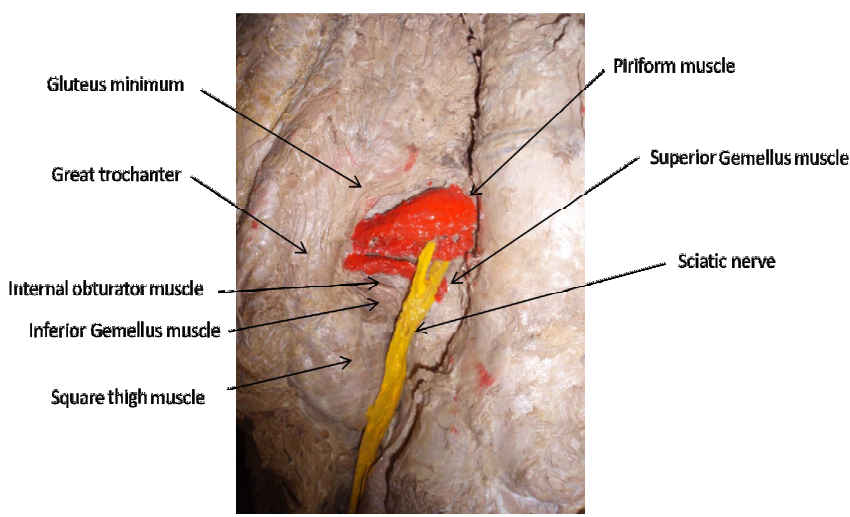

Figure 2 - Dissected gluteal region showing the type $B$ anatomical variation of the path of the sciatic nerve in relation to the piriform muscle, according to the criteria of Beaton $^{11}$. 
Table 1 - Classification of Beaton ${ }^{11}$ for anatomical variations of the sciatic nerve in relation to the piriform muscle.

\section{Type Nerve path}

(A) Sciatic nerve inferior to piriform muscle.

(B) Fibular component passing through the belly of the piriform muscle.

(C) Superior Fibular and tibial components inferior to the piriform muscle.

(D) The entire sciatic nerve passing through the piriform muscle.

(E) Superior Fibular and tibial components passing through the piriform muscle.

(F) The entire sciatic nerve superior to the piriform muscle.

\section{RESULTS}

With the completion of the dissection of the 40 gluteal regions of the 20 cadavers available, we observed that 34 gluteal regions of 17 corpses had bilateral type A relationship between the sciatic nerve and the piriform muscle. Two male corpses, one brown and one black, showed a bilateral fibular trunk of the sciatic nerve going through the belly of the piriform muscle and the tibial stem passing below the muscle, characterizing a type $B$ of the mentioned classification: one black, male cadaver presented type $B$ in the right hip and type $A$ in the left hip. There were no variations of types $C, D, E$ and $\mathrm{F}$ (Table 2).

The average distance between the lateral nerve border and the route of the arthroscopic portal was $2.98 \mathrm{~cm}$ and the median, $2.90 \mathrm{~cm}$, ranging from $2.1 \mathrm{~cm}$

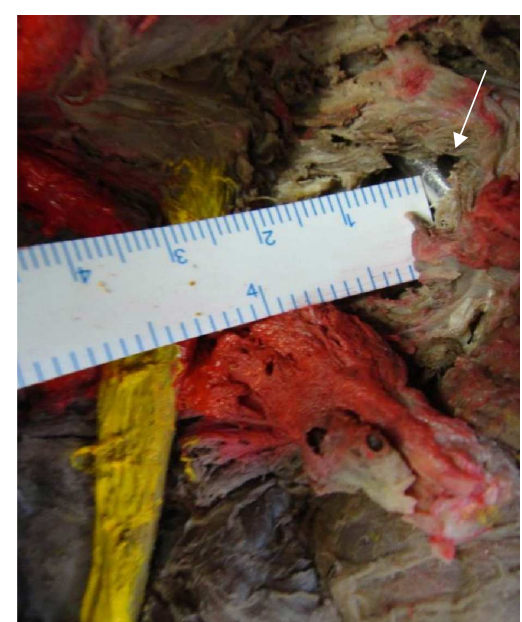

Figure 3 - Measurement of the distance between the sciatic nerve and the path of arthroscopic trocar (arrow).

Table 2 - Data found on dissection of anatomical parts.

\begin{tabular}{|c|c|c|c|c|c|}
\hline \multirow[t]{2}{*}{ Corpse } & \multirow[t]{2}{*}{ Gender } & \multirow[t]{2}{*}{ Color } & \multirow[t]{2}{*}{ Classification } & \multicolumn{2}{|c|}{ DSP } \\
\hline & & & & (D) & AND \\
\hline 1 & $(\mathrm{~F})$ & White & (A) & 2.4 & 2.5 \\
\hline 2 & $(\mathrm{~F})$ & Brown & (A) & 2.2 & 2.3 \\
\hline 3 & $M$ & White & (A) & 2.1 & 2.3 \\
\hline 4 & M & White & (A) & 3.7 & 3.6 \\
\hline 5 & $M$ & Black & (A) & 4.0 & 4.1 \\
\hline 6 & $M$ & Black & (A) & 3.2 & 3.2 \\
\hline 7 & $M$ & Brown & (B) & 2.2 & 2.3 \\
\hline 8 & $M$ & Black & (A) & 3.2 & 3.2 \\
\hline 9 & $M$ & White & (A) & 4.0 & 3.9 \\
\hline 10 & $M$ & Brown & (A) & 3.5 & 3.5 \\
\hline 11 & $M$ & Black & (B) & 2.5 & 2.4 \\
\hline 12 & $M$ & White & (A) & 2.9 & 2.9 \\
\hline 13 & $M$ & Brown & (A) & 2.8 & 3.0 \\
\hline 14 & (F) & White & (A) & 2.4 & 2.4 \\
\hline 15 & M & White & (A) & 3.2 & 3.0 \\
\hline 16 & $M$ & Brown & (A) & 2.8 & 2.9 \\
\hline 17 & $M$ & White & (A) & 3.7 & 3.5 \\
\hline 18 & $M$ & Black & (B) (D)/A (E) & 2.9 & 2.7 \\
\hline 19 & $M$ & Black & (A) & 3.6 & 3.4 \\
\hline 20 & $M$ & Brown & (A) & 2.5 & 2.6 \\
\hline
\end{tabular}

* D-Right; + E-left; $\neq$ F-Female; \& M-Male;

** DSP - distance between the sciatic nerve and the portal path. 
and $4.1 \mathrm{~cm}$. The average distance found among the hips classified as type A was $3.06 \mathrm{~cm}$, and as type B, 2.46 $\mathrm{cm}$. After applying the Wilcoxon nonparametric test for relating the distance between the arthroscopic portal and the sciatic nerve in the two different anatomical settings, we found a p-value of 0.0254 , and at t test, a p value of 0.0028 , with a $95 \%$ confidence interval, showing statistical reliability.

\section{DISCUSSION}

Beaton and Anson ranked the anatomical variations between the piriform muscle and the sciatic nerve in 1938. By dissecting 240 gluteal regions, they found $10 \%$ of anatomical variations, with $7.1 \%$ type B, $2.1 \%$ type $C$ and $0.8 \%$ type $D, 66 \%$ of them bilateral ${ }^{11}$. Dalley found similar data, $12.2 \%$ type B and $0.5 \%$ type C, after dissection of 640 cadavers, this being the greatest sample found in the literature ${ }^{13}$. In his surgical anatomy work, Rosse found $84 \%$ of the gluteal regions without anatomical variation, $12 \%$ type $B, 3 \%$ type $C$ and $1 \%$ type $D^{14}$.

Analyzing the data found $11,13,14$, we observed

that in $87.1 \%$ of cadavers the sciatic nerve anatomy had no change. The most common change was type $B$, averaging $10.47 \%$ of occurrence. The type $C$ was found in $1.87 \%$ of cases, and type $D$, only $0.6 \%$. Types $E$ and $F$ are hypothetical ${ }^{11}$, with no account in the literature. After dissecting 40 gluteal regions of 20 cadavers, we found three type B variations, corresponding to $2.5 \%$ of the sample, two of them bilateral, corresponding to $66.6 \%$ bilaterality, and one unilateral. The results obtained are thus similar to those found in the literature. There is a consensus in relation to the risk of neurological damage during hip arthroscopy, the pudendal nerve lesion being cited with more frequency. These lesions are usually neuropraxis due to the stretch of the orthopedic traction table, and are fully reversed in most cases in up to three weeks, hardly leaving permanent sequel ${ }^{4}$. Lo et al. analyzed 73 arthroscopic procedures in 72 patients and reported five cases (7\%) of the sciatic neuropraxis, with complete regression of all cases in two weeks after the operation ${ }^{15}$. In a prospective study, Birmingham carried out somatosensory evoked potential monitoring of the tibial and common peroneal nerves and found that 35 (58\%) of 60 patients had intraoperative neurological dysfunction, $4(7 \%)$ of them with clinical injury after the procedure ${ }^{6}$ He related the worst results with anatomical variations, bodily habits and patient positioning on the traction table, with higher incidence of pudendal nerve involvement in the supine position and the sciatic nerve in the lateral position ${ }^{6}$. Farjo * $\%$. evaluated 28 patients undergoing arthroscopic treatment of acetabular labrum injury and observed three neuropraxis, fully reversed in two weeks, one of the pudendal nerve and two of the sciatic ${ }^{16}$. Griffin and Villar analyzed 640 hip arthroscopies, reporting three transitional sciatic nerve paralysis, one of the femoral nerve and one of the pudendal, all attributed to prolonged time and excessive traction ${ }^{17}$. In more prolonged procedures it is recommended that traction application is conducted intermittently and that the its strength does not exceed the weight of $22.7 \mathrm{~kg}$ (50 pounds). Assessments held during the traction showed that the neurovascular structures become more fixed and lateralized, with increased susceptibility to direct iatrogenic injury ${ }^{4}$. The use of traction with intense flexion was related to a higher chance of damaging the sciatic nerve ${ }^{16}$. There is debate on the risks associated with the penetration of the soft tissues around the hip. However, Byrd and Chern dissected eight corpses for assessment of structures in risk and reported two cases of direct injury of the lateral cutaneous nerve of the thigh ${ }^{18}$. Bruno et al. Reported a case of irreversible injury of the sciatic nerve, of compression character, due to pseudoaneurysm formation of inferior gluteal artery in a 61-year-old woman ${ }^{19}$.

Anatomical variations of nerve pathway can also cause chronic pain. Polesselo et al. reported a case of deep gluteal pain in a 42-year-old women, with 17 years of evolution, due to an anatomical variation of the sciatic nerve in relation to the piriform muscle, confirmed with neurography with aid of magnetic resonance ${ }^{20}$

Little is said about the direct injury of the sciatic nerve during the establishment of the posterior portal, but we care to mention the close relationship between the anatomical structure and the posterior access point. Byrd dissected eight frozen fresh cadavers to assess this relationship and found an average distance of $2.9 \mathrm{~cm}$, ranging between 2.0 and $4.3 \mathrm{~cm}^{7}$. Upon literature review, we found no relationship between the distance from the nerve to the portal and the Beaton criteria.

In conclusion, the making of the posterior arthroscopic portal to the hip joint must be done with careful marking of the trochanteric massive; should there be any difficulty to locate it, a small surgical access is recommended. The access point to the portal should not exceed two centimeters posteriorly towards the posterior-superior aspect of the greater trochanter, and should be made with the limb in 15 degrees internal rotation. 


\section{R E S U M O}

Objetivo: avaliar a relação anatômica topográfica entre o nervo ciático, em relação ao músculo piriforme, e o portal posterior utilizado para a realização da artroscopia de quadril. Métodos: foi realizada a dissecção de 40 quadris, de 20 cadáveres, indivíduos adultos, brasileiros, sendo 17 do sexo masculino e três do feminino, seis negros, seis pardos e oito brancos. Foram estudadas a relação anatômica entre o nervo ciático e o músculo piriforme com suas respectivas variações e a distância entre o bordo lateral do nervo ciático e o portal posterior, utilizado na artroscopia de quadril. Foram classificadas as alterações anatômicas encontradas no trajeto do nervo ciático relativo ao musculo piriforme. Resultados: dezessete cadáveres apresentavam bilateralmente a relação entre o nervo ciático e o músculo piriforme enquadradas no tipo A. Foram encontradas as seguintes variações anatômicas: $12,5 \%$ de variante tipo $B$ e uma distância média entre o nervo ciático e o portal para artroscopia de $2,98 \mathrm{~cm}$. Um corpo apresentava variação anatômica tipo B no quadril esquerdo e tipo A no direito. Conclusão: a confecção do portal artroscópico posterior para a articulação do quadril deve ser realizada com marcação criteriosa do maciço trocantérico; havendo dificuldade para localizá-lo, recomenda-se um pequeno acesso cirúrgico. O ponto de acesso para o portal não deve ultrapassar dois centímetros em direção posterior à faceta póstero-superior do grande trocanter, e deve ser confeccionado com o membro em rotação interna de 15 graus.

Descritores: Artroscopia. Quadril. Variação anatômica. Nervo ciático. Ortopedia.

\section{REFERENCES}

1. Burman MS. Arthroscopy or the direct visualization of joints: an experimental cadaver study. Clin Orthop Relat Res. 2001;(390):59.

2. Takagi K. The classic. Arthroscope. Kenji Takagi. J. Jap. Orthop. Assoc., 1939. Clin Orthop Relat Res. 1982;(167):6-8.

3. Glick JM, Sampson TG, Gordon RB, Behr JT, Schmidt E. Hip arthroscopy by the lateral approach. Arthroscopy. 1987;3(1):412.

4. Papavasiliou AV, Bardakos NV. Complications of arthroscopic surgery of the hip. Bone Joint Res. 2012;7(1):131- 44.

5. McCarthy JC. Hip arthroscopy: applications and technique. J Am Acad Orthop Surg. 1995;3(3):115-22.

6. Birmingham P. Hip arthroscopy neuropraxia: is it only about weight of traction? J Bone Joint Surg Am. 2012;94(22):e169.

7. Byrd JW, Pappas JN, Pedley MJ. Hip arthroscopy: an anatomic study of portal placement and relationship to the extra-articular structures. Arthroscopy. 1995;11(4):418-23.

8. Dvorak M, Duncan CP, Day B. Arthroscopy anatomy of the hip. Arthroscopy. 1990;6(4):264-73.

9. Robertson WJ, Kelly BT. The safe zone for hip arthroscopy: a cadaveric assessment of central, peripheral and lateral compartment portal placement. Arthroscopy. 2008;24(9):101926.

10. Byrd JWT, editor. Operative hip arthroscopy. 2th ed. New York: Thieme; 1998.

11. Beaton $L E$, Anson $B J$. The sciatic nerve and the piriformis muscle: their interrelation a possible cause of coccygodynia. J Bone Joint Surg Am. 1938;20(3):686-8.
12. Chiba S. Multiple positional relationships of nerves arising from the sacral plexus to the piriforms muscle in humans. Kaibogaku Zasshi. 1992;67(6):691-724.

13. Moore KL, Dalley AF. Anatomia orientada para a clínica. $4^{\mathrm{a}}$ ed. Rio de Janeiro: Guanabara Koogan; 2001.

14. Rosse C, Gaddum-Rosse P, Hollinshead WH, editors. Hollinshead's Textbook of anatomy. $5^{\text {th }}$ ed. Philadelphia: Harper and Row; 1982.

15. Lo YP, Chan YS, Lien LC, Lee MS, Hsu KY, Shih CH. Complications of hip arthroscopy: analysis of seventy three cases. Chang Gung Med J. 2006;29(1):86-92.

16. Farjo LA, Glick JM, Sampson TG. Hip arthroscopy for acetabular labral tears. Arthroscopy. 1999;15(2):132-7.

17. Griffin DR, Villar RN. Complications of arthroscopy of the hip. J Bone Joint Surg Br. 1999;81(4):604-6.

18. Byrd JW, Chern KY. Traction versus distension for distraction of the joint during hip arthroscopy. Arthroscopy. 1997;13(3):346-9.

19. Bruno M, Longhino V, Sansone V. A catastrophic complication of hip arthroscopy. Arthroscopy. 2011;27(8):1150-2.

20. Polesello GC, Queiroz MC, Linhares JPT, Amaral DT, Ono NK. Variação anatômica do músculo piriforme como causa de dor glútea profunda: diagnóstico por neurografia RM e seu tratamento. Rev bras ortop. 2013;48(1):114-7.

Received 06/11/2013

Accepted for publication 10/02/2014

Conflict of interest: none.

Source of funding: none.

Mailing address:

Berliet Assad Gomes

Email: berliet@artroquadril.com.br; berliet@ibest.com.br 